\title{
E-G overnment and the Transformation of Service Delivery and Citizen Attitudes
}

The impact of new technology on public-sector service delivery and citizens' attitudes about government has long been debated by political observers. This article assesses the consequences of egovernment for service delivery, democratic responsiveness, and public attitudes over the last three years. Research examines the content of e-government to investigate whether it is taking advantage of the interactive features of the World W ide W eb to improve service delivery, democratic responsiveness, and public outreach. In addition, a national public opinion survey examines the ability of e-government to influence citizens' views about government and their confidence in the effectiveness of service delivery. Using both W eb site content as well as public assessments, I argue that, in some respects, the e-government revolution has fallen short of its potential to transform service delivery and public trust in government. It does, however, have the possibility of enhancing democratic responsiveness and boosting beliefs that government is effective.

The impact of new technology on information access, government service delivery, and public attitudes about government has long been debated by observers. Each technological innovation-from the movable-type printing press in the fifteenth century, the telegraph in 1844, and the telephone in 1876, to the rise of radio in the 1920s and coast-to-coast television broadcasting in 1946-has sparked speculation about its longer-term social and political impact. Transformationalists often predict widespread consequences arising from new technology, while incrementalists note the constraining influence of social, economic, and institutional forces on the ability of technology to alter behavior (Bowie 1996; Margolis and Resnick 2000; Davis 1999).

In the debate over the transforming power of new technology, it is important to remember that change represents a continuum characterized by relative comparisons of time and pace. There are three dimensions of change that are important for new technology: long-term versus short-term impact, big versus little shifts, and technocratic versus political and institutional alterations. Given the complexity of change assessments, it is difficult to determine how much innovation and how long a period of time is required before something can be considered a "complete change in character, condition," the classic definition of transformation.
One thing that is clear about technological change discussions is that they often focus on the endpoints of change comparisons, without looking at the direction and degree of change or identifying which particular dimension of change is being evaluated. Lindblom's (1959) pathbreaking work on "muddling through," for example, focused on decision-making processes. Is change rational and dictated in key respects by economic trade-offs, or is it a political process characterized by small-scale shifts constrained by budgetary and institutional processes? Wildavsky (1984) generalized Lindblom's process model to policy outputs and suggested that government policies typically evolve through small-scale steps, not large-scale transformations.

Other authors have emphasized the importance of looking at the middle of the change spectrum and proposed models that outline how "constrained change" unfolds. Quinn (1992) develops a model of "logical incrementalism," which suggests that significant change can take place within organizations on a step-by-step basis, even outside of a revolutionary change model. In the same vein, Fountain's (2001a ) notion of "enacted technology" discusses

Darrell M. West is the John Hazen W hite Professor of Political Science and Public Policy and director of the Taubman Center for Public Policy at Brown University. He is the developer of the Web site InsidePolitics.org, which features in-depth analysis of city, state, federal, and global e-government. He is the author of 11 books, including The Rise and Fall of the Media Establishment (2001). E-mail: Darrell_West@ brown.edu. 
change that is substantial even if it trails optimistic projections of proponents.

Because it is impossible to know whether a particular technological innovation will produce large-scale or smallscale change until years have passed, it makes sense for researchers to focus on the nature and direction of new practices in the short-run. The virtue of studying shortterm change is that it provides hints about longer-term shifts and gives policy makers benchmarks for evaluating how close they are to achieving particular goals and outcomes.

This article assesses the debate over technological change by examining the short-term nature and direction of electronic government for public-sector service delivery and citizen attitudes. The content of e-government is investigated to see whether it has taken advantage of the interactive features of the World Wide Web to improve service delivery, democratic responsiveness, and public outreach over the last three years. In addition, a 2000 national public opinion survey is used to explore e-government's ability to affect citizens' views about government and their confidence in the effectiveness of service delivery. Using both content measures as well as public assessments, I argue that, in some respects, e-government has fallen short of its potential to transform government service delivery and trust in government. It does, however, offer the prospect of enhancing democratic responsiveness and boosting beliefs that government is effective.

\section{The Nature and Direction of E-G overnment Practices}

E-government refers to the delivery of government information and services online through the Internet or other digital means. Unlike traditional structures, which are hierarchical, linear, and one-way, internet delivery systems are nonhierarchical, nonlinear, two-way, and available 24 hours a day, seven days a week. The nonhierarchical character of internet delivery frees citizens to seek information at their own convenience, not just when a government office is open. The interactive aspects of e-government allow both citizens and bureaucrats to send and receive information. By facilitating two-way interaction, electronic governance has been hailed as a way to improve service delivery and responsiveness to citizens, in the long run generating greater public confidence in government (Gore 1993; Markoff 2000; Raney 2000).

These novel aspects of digital technology led Reed Hundt, former chairman of the Federal Communications Commission, to conclude that "the central lesson of technology in our time is this: The Internet Changes Everything. The lesson applies to the economy, education, community, individualism, and ... democracy" (quoted in Kamarck and Nye 1999). With regard to the political pro- cess, writers such as Dennis Thompson have suggested that some aspects of interactive technologies bring about change because they weaken the factionalization that plagues political systems. New technologies enhance communication by overcoming geographical distance, promoting ideological variety, opening citizens to more diverse viewpoints, and encouraging deliberation (Thompson 1999, 36-37). The interactive nature of Internet technology, plus its ability to speed communications, has the potential to make governance function better than it currently does.

Others have written about the capacity of the Internet to transform bureaucracy. Jane Fountain has discussed the way in which information technology (IT) alters the capacity and control features of traditional bureaucracies. IT, she notes, has the potential "to substantially redistribute power, functional responsibilities, and control within and across federal agencies and between the public and private sectors" (Fountain 1999, 150; 2001a). By encouraging bureaucrats to work together and develop cross-agency "portals"-Web sites that integrate information and service offerings-e-government offers the prospect of considerable change in how the public sector functions. Indeed, Fountain cites estimates demonstrating "cost performance ratios to be declining at a rate of $20-30$ percent a year" (Fountain 1999, 142).

However, anticipation about the manner in which the Internet will transform government runs squarely into the alternative interpretation of incrementalism (Lindblom 1959; Wildavsky 1984). There are clear reasons why much political change tends to be small-scale and incremental rather than transformational. Government actions are mediated by a range of factors: institutional arrangements, budget scarcity, group conflict, cultural norms, and prevailing patterns of social and political behavior, each of which restricts technology's ability to transform society and politics (Fountain 2001b). The fact that governments are divided into competing agencies and jurisdictions limits policy makers' ability to get bureaucrats to work together to promote technological innovation. Budget considerations restrict the ability of government offices to place services online and to use technology for democratic outreach. Groups fight over whether online tax filing should be left to the private sector or performed by the government. Cultural norms and patterns of individual behavior affect the manner in which technology is used by citizens and policy makers.

Political constraints are so severe that Richard Davis (1999), Michael Margolis and David Resnick (2000), and Andrew Chadwick (2001) predict that, in the long run, Internet technology will not transform democracy. If anything, technology reinforces existing social and political patterns. In regards to technology, Davis notes, "that complex bureaucratic maze also has been duplicated on the 
Web.” Agency Web sites serve to perpetuate their own mission and do little to enhance responsiveness or citizen participation (Davis 1999, 146-48). Margolis and Resnick (2000, vii) argue that "far from revolutionizing the conduct of politics and civic affairs in the real world, we found that the Internet tends to reflect and reinforce the patterns of behavior of that world." Chadwick (2001) finds government Web sites in the United States, Great Britain, and the European Union to be "predominantly non-interactive and non-deliberative," and concludes that e-government is not likely to reshape governance.

These arguments about the long-term impact of the Internet, however, require data on the nature and direction of current e-government practices. Assuming that electronic government falls along a continuum from transformation to incrementalism, scholars must develop short-term benchmarks that measure the relationship between electronic government and service delivery, democratic responsiveness, and citizens' attitudes about government. By looking at preliminary data collected early in the "e-government revolution," this article examines the consequences of new technology for political and governmental processes and provides hints about the future of digital government.

\section{Stages of E-G overnment Transformation}

In thinking about the stages of e-government transformation, it is helpful to outline how to measure the extent of change. There are four general stages of e-government development that distinguish where different government agencies are on the road to transformation: (1) the billboard stage; (2) the partial-service-delivery stage; (3) the portal stage, with fully executable and integrated service delivery; and (4) interactive democracy with public outreach and accountability enhancing features.

This categorization does not mean that all government Web sites go through these steps or that they undertake them in this particular order. It is clear from looking at thousands of agency Web sites there is a wide variety of ways that e-government has evolved in different cities, states, and countries. However, based on our research, this sequence appears to be a prevalent course of development in many agencies. The commonality of this model, therefore, allows researchers to determine an agency's progress based on how far along they are at incorporating various Web site features.

In the first stage, officials treat government Web sites much the same as highway billboards, that is, static mechanisms to display information. They post reports and publications and offer data bases for viewing by visitors. There is little opportunity for citizen interaction or two-way communication between citizens and officials. Citizens can read government reports, see the text of proposed legislation, and find out who works in specific offices but they cannot manipulate information or interact with it in any way other than viewing. The public generally is limited to seeing information in the form put together by officials.

This stage gives way to one emphasizing partial service delivery. Citizens can order and execute a handful of services online and start to manipulate informational databases. They can search Web sites for material they want to see, as opposed to the information officials want to present to them. This helps them access materials in the form they prefer. However, online service possibilities are sporadic and limited to a very few areas. Posting of privacy and security statements are not very abundant, and there isn't much accessibility for non-English speakers and the disabled.

The third stage is a one-stop government portal with fully executable and integrated online services. This phase offers considerable convenience to visitors. The entire city or state has one place where all other agencies can be accessed, which improves citizen ability to find information. Agency sites are integrated with one another, and a range of fully executable services are available to citizens and businesses. Officials show they pay attention to the public's privacy and security concerns by posting policies online. Translation options are available for those who do not speak English or those who are visually or hearing impaired.

The fourth stage is interactive democracy with public outreach and a range of accountability measures. Here, government Web sites move beyond a service-delivery model to systemwide political transformation. In addition to having integrated and fully executable online services, government sites offer options for Web site personalization (such as customizing for someone's own particular interests) and push technology (such as providing e-mails or electronic subscriptions that provide automatic updates on issues or areas people care about). These kinds of features help citizens customize information delivery and take advantage of the interactive and two-way communications strengths of the Internet. Through these and other kinds of advanced features, visitors can personalize Web sites, provide feedback, make comments, and avail themselves of a host of sophisticated features designed to boost democratic responsiveness and leadership accountability.

\section{Data and Methodology}

With the new and constantly changing nature of the Internet, it is no big surprise there has been little empirical research to test key research claims about e-government. Of the empirical projects that have looked at e-government, most have limited their analysis to single American states or small numbers of Web sites, weakening the generalizability of the findings. For example, Musso, Weare, and 
Hale (2000) examine 270 municipal government Web sites in California and find that few sites emphasize democratic participation. But we don't know whether their conclusions hold up for the remaining 49 states. Chadwick (2001) studies the United States, Great Britain, and the European Union and uncovers little evidence of political transformation, though he looked only at 38 government agency Web sites.

An e-mail survey conducted in the summer of 2000 with chief information officers in the 50 states and 38 major federal agencies discovered an optimistic view among policy makers regarding the transformational power of the Internet. ${ }^{1}$ That survey asked several questions about the information officers' views of the impact of e-government. Among the items were the following three questions: "Do you think e-government has made your state (or federal) government more efficient?" (yes or no); "Has e-government helped your state (or federal) government reduce the costs of service delivery?" (yes or no); and "Has e-government improved the delivery of public services in your state (or federal agency)?" (yes or no). In general, the respondents were remarkably positive about the capacity of the Internet to transform government: Eighty-six percent felt e-government had already improved service delivery, 83 percent believed it had made government more efficient, and 63 percent claimed it had reduced government costs.

Such responses, however, are limited because they are based on perceptions, not assessments of actual Web sites, budget figures, or service delivery. Chief information officers have a self-interested stake in promoting the view that what they are doing is effective, efficient, and responsive. As such, their perceptions are prone to exaggeration.

In order to develop a more realistic assessment of egovernment's impact, this research examines four different data sets designed to investigate how e-government is affecting service delivery, democratic responsiveness, and public opinion about government. How many and what types of information and services have been placed online, and how has this distribution changed over time? Are government officials responsive to citizen requests for information, and do they incorporate "responsiveness-enhancing" technologies on government Web sites? How do ordinary citizens evaluate e-government? Does the use of government Web sites encourage citizens to become more trusting in government and more likely to think the government is effective at service delivery?

First, I examined budget data outlining state government expenditures on information technology for fiscal years 1998, 1999, and 2000. This information was compiled by the National Association of State Information Resource Executives (now renamed NASCIO), the professional association of state chief information officers. These data show the percentage of the state budget devoted to infor- mation technology and how those figures changed between 1998 and 2000. Of the 50 states surveyed by NASCIO, 46 percent ( 23 states) provided information technology budget figures. The 27 states that are not included in this data set chose not to make information available on their technology spending.

Second, I present the results of two detailed content analyses of U.S. state and federal government Web sites: 1,813 government Web sites analyzed in the summer of 2000 , and a follow-up study of 1,680 government Web sites evaluated in the summer of 2001 . For each content study, a team of research assistants undertook a comprehensive analysis of all of the major state and federal government Web sites in the United States. This included sites from each branch of government in both levels of government. Among the sites analyzed were those developed by court offices, legislatures, Congress, state and national officials, major cabinets and departments, and state and federal agencies serving crucial government functions such as health, human services, taxation, education, corrections, economic development, administration, natural resources, transportation, elections, and business regulation. Web sites for obscure state boards and commissions, local government, and municipal offices were excluded from the study. An average of 34 Web sites was studied for each state in 2000 and 32 sites per state in 2001.

Recognizing there is no agreement on appropriate benchmarks or what constitutes an effective government Web site, public-sector sites were reviewed based on the various stages of e-government. Researchers looked for a range of online features that citizens have reported to be important in market research and opinion surveys: (1) billboard features such as contact information, publications, and databases; (2) service delivery number, diversity, and integration; and (3) public outreach and democracy enhancement, such as comment boards, Web site personalization, automatic e-mail updates, search features, and broadcast information.

A range of features were examined, such as having privacy and security policies, providing language-translation options, and serving populations with special needs such as the disabled. Each Web site was evaluated for the presence (coded 1) or absence (coded 0) of 27 different features at the point in time we visited that site. ${ }^{2}$ The entire site (not just a few pages) for every agency was studied to provide a complete picture of its contents.

In addition, to see how citizens felt about e-government, I analyzed the raw data of a national public opinion survey conducted August 14-16, 2000, with 1,003 randomly sampled adults across the United States. This telephone survey had a margin of error of \pm 3.5 percentage points and was undertaken by the polling firm of Peter Hart/Robert Teeter of Washington, DC, on behalf of the Council for 
Excellence in Government, a Washington nonprofit organization dedicated to improving the functioning of government. This survey sample was developed using randomdigit-dialing sampling techniques and included an oversample of 200 frequent Internet users. Data were weighted in accordance with the demographic composition of the United States population. Seventy-nine questions were included in the survey, including items measuring the use of government Web sites, evaluations of e-government (ease of finding sites, overall rating, and past and future positive impact), views about government and political activity (trust in government, confidence in government, views about government effectiveness, and measures of political activity), and common political and demographic controls (sex, age, race, income, education, and party identification). See the appendix for survey questions.

Finally, to examine responsiveness to citizen requests, our research team sent an e-mail to four offices in each state: the governor, the legislature, the top state court, and the major human services agency, as well as to all major federal agencies. The message asked a simple question: "I am trying to find out when your agency is open. Could you let me know the official hours your office is open? Thanks for your help." E-mail responses were recorded based on the number of business days it took each agency to respond. This helped to measure how responsive agencies were to simple citizen requests for information.

Because e-government change is a continuum running from incremental to transformational impact, data are presented that show the nature and direction of change along a number of different dimensions. This allows researchers to compare the relative degree of change over the last few years and against the optimistic projections of e-government officials (Gore 1993). For calibration along this continuum, the article employs the four stages of e-government (billboard, partial service delivery, portal, interactive democracy) to show how much progress public-sector agencies have made.

For the analysis, I test a number of specific and general hypotheses about technological change in e-government:

1. State budget expenditures on information technology-State spending on information technology will be low and relatively stable over time.

2. Online information-State and federal government Web sites will have high levels of information and publications online for citizen access, but with little change from year to year.

3. Online services-State and federal government Web sites will have many online services available for citizen use.

4. Use of credit cards and digital signatures for online services-State and federal government Web sites will allow the use of credit cards and digital signatures to help citizens access services and make legal and financial transactions online.

5. Online privacy and security - State and federal government Web sites will devote special attention to reassuring visitors about privacy and security because public opinion surveys have documented clear citizen concern in these areas.

6. Accessibility features for special populations such as the disabled and non-English speakers-State and federal government Web sites will use technology to provide accessibility to the disabled and those who do not speak English.

7. Use of commercial advertising - State and federal government Web sites will make little use of commercial advertising, consistent with past tendencies discouraging public-sector advertising.

8. Democratic responsiveness-State and federal government Web sites will use interactive features (e-mail, bulletin boards for citizens to post comments, and push technologies) to enhance responsiveness and to improve the functioning of the political system.

9. Visits to government Web sites-Large numbers of citizens will report they make use of government Web sites.

10. Public trust and confidence in government-E-government usage will be linked to high citizen trust and confidence in government.

The remainder of this article reports the results of the data analysis and shows the nature and direction of current e-government practices. After summarizing the results in areas ranging from budget expenditures and government information and service delivery to democratic responsiveness and public opinion, the research draws conclusions about the transforming potential of electronic government.

\section{State Budget Expenditures on Information Technology, 1998-2000}

Spending data provided by state chief information officers suggest incremental change. As table 1 shows, most of the 23 states that provided budget information are spending relatively small portions ( 1 percent to 2 percent) of their overall budget on information technology, and spending has been relatively stable over the last three years. Obviously, there are no data from the other 27 states (including technology innovators such as California and New York). But the jurisdictions that did provide information include both large states (Texas, Ohio, Michigan, and Pennsylvania) and small states, as well as a mix of "innovating" and "following" states.

The bivariate Pearson correlation between IT expenditures in FY98 and FY99 is 0.92 (significant at 0.001); between FY99 and FY00 is 0.97 (significant at 0.001); and 


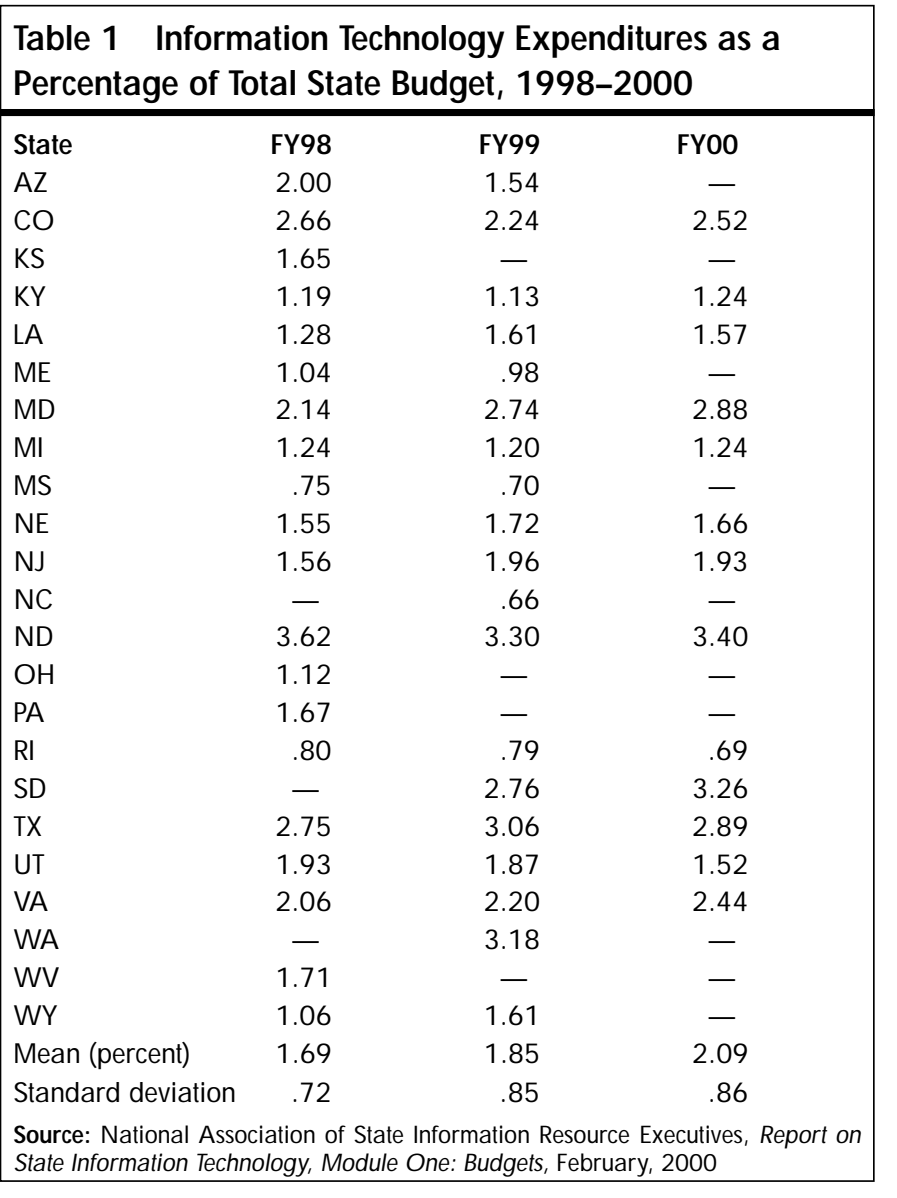

between FY98 and FY00 is 0.93 (significant at 0.001). This means that at least 85 percent of the variation in FY99 spending can be predicted by what was spent in FY98. For FY00, one can predict 94 percent of the variation in state IT spending through FY99 expenditures. These findings are consistent with the budgeting literature, which shows that-barring such examples as state corrections during the 1990s, which experienced rapid and substantial budget increases as a result of crackdowns on crime and the resulting increase in prison populations-most categories of state expenditures remained stable over the last decade. As the incremental budget model suggests (Wildavsky 1984), the strongest predictor of one year's IT budget is that of the previous year.

\section{The Content of E-G overnment, 2000 and 2001}

An examination of information technology expenditures at the state level tells us little about how technology is being used in the public sector. To see what is online at government sites, an extensive content analysis of state and federal government sites was undertaken in 2000, followed by a similar update in 2001 . The results show that in many respects, e-government is consistent with incrementalism, although in a few ways, technology is transforming the type of material available to people.
In general, government Web sites are doing a good job of providing their department's telephone number (94 percent in 2001, compared to 91 percent in 2000) and address (93 percent, as opposed to 88 percent last year). There also have been improvements in access to publications ( 93 percent in 2001, versus 74 percent in 2000) and databases (54 percent in 2001, compared to 42 percent in 2000). The relatively stable results from year to year demonstrate that egovernment improvements in these areas are proceeding within a pattern of "normal politics." Most agencies have been successful at developing billboard-style e-government and putting a few services online.

However, fully executable, online service delivery was not prevalent on most government Web sites, nor were agency offerings very well integrated with one another. Despite e-government rhetoric, which promises to bring services directly into the homes of citizens (Gore 1993), only 25 percent of the sites offered online services in 2001, up slightly from 22 percent in 2000 . Features were defined as "services" if the entire transaction could occur online. If a citizen had to download a form for a service and then mail it back to the agency, we did not count that as a service that could be fully executed online. ${ }^{3}$

In 2000 and 2001, both state and federal Web sites were attempting to make it easier for citizens to access online services through portals, that is, one-stop centralized pages where citizens can access all of the services within that state. Meanwhile, the federal government has developed firstgov.gov, which links to all national-level agencies and departments. But neither that site nor many states offer a fully integrated government service portal. ${ }^{4}$ This suggests that many government offices lie somewhere between partial service and fully functioning portals with many services online and fully integrated technological features.

Two practices that would speed the ability of government sites to offer services and to handle financial transactions are credit cards and digital signatures. However, consistent with a model of incremental change, most sites provided neither. Only 10 percent of sites in 2001 accepted credit card payments, up from 3 percent in 2000. Less than 1 percent of government Web sites allowed digital signatures for legal documents or financial transactions. The small number of sites permitting either one of these options limits the ability of available technology to transform service delivery. Unless citizens are able to complete services and legal or financial transactions online, e-government will not be able to make much progress at altering conventional patterns of service delivery through office visits, telephone calls, and personal mail.

The free-flowing atmosphere of the Internet has prompted many to question the privacy and security of government Web sites. National public opinion surveys undertaken by the Council for Excellence in Government, 
place these areas near the top of the list of citizen concerns about e-government. Thus, visible statements that outline what the site is doing are a valuable asset for reassuring the public. While a growing number of sites offer privacy statements (28 percent in 2001, versus 7 percent in 2000), three-quarters have no such reassurances. The same is true in the area of security: Eighteen percent now have a visible security policy, up from 5 percent last year. ${ }^{5}$ Clearly, there has been no dramatic transformation in the visibility of privacy and security statements which would reassure a public that is worried about the Internet.

In addition, little is being done to address the needs of special populations such as the disabled and non-English speakers. Only 27 percent of government Web sites in 2001 (up from 15 percent in 2000) have some form of disability access, and 6 percent offer foreign language translation (up from 4 percent in 2000). To be recorded as accessible to the disabled, the site had to have either a TTY (text telephone) or TDD (telephonic device for the deaf) phone number, which allows hearing-impaired individuals to contact the agency by phone; be "Bobby approved," meaning that the site has been deemed disability accessible by a nonprofit group that rates Internet sites; or meet the standards of the World Wide Web Consortium or legislative acts such as Section 508 of the U.S. Rehabilitation Act of 1973.

An aspect of government Web sites that fits squarely into an incrementalist model is the near-total absence of advertisements by commercial enterprises. Long discouraged in the public sector by people who fear conflicts of interest (potential or actual), most government agencies do not carry ads in their official publications (except for tourism agencies) or in their buildings (except for transit buses that feature display ads). To see how government Web sites handled this question, we examined them for the presence of commercial advertising. Of the sites examined, 2 percent had some sort of advertisement, the same as in the previous year. When defining advertisements, we eliminated computer software available for free download (such as Adobe Acrobat Reader, Netscape Navigator, and Microsoft Internet Explorer) because they are necessary for viewing particular products or publications. Links to products or services available for a fee, such as commercial tax preparation software, were included as advertisements, as were traditional banner-style advertisements. Examples of advertisements on the states' sites were for E-File (online income tax filing software available through purchase), various radio and television stations, Fidelity Investments, IBM, Hilton Hotels, Prudential, Pfizer, Barnes and Noble, Dow Chemicals, and Compaq.

Judging from the content of nearly 3,500 government Web sites examined in 2000 and 2001, then, there is little empirical evidence to support a "complete change in character, condition" of service delivery in the United States.
While there have been rapid advances in putting publications and contact information online (consistent with the billboard stage) and some progress in getting a few services online (consistent with the partial-service-delivery stage), there has been little integration of portals with agencies, not very many services put online, and little progress on citizen concerns regarding security, privacy, and disability access (features associated with a fully integrated and executionable portal). While technology has the potential to alter government service delivery in the future and to enhance overall system performance, its current usage has not produced dramatic changes or much evidence of the fourth stage of e-government-interactive democracy.

\section{Democratic 0 utreach and Responsiveness}

E-government planners have touted technology's potential to transform the public sector by bringing citizens closer to government (National Performance Review 1993). Although the technology to facilitate greater responsiveness is readily available, many government sites have not taken full advantage of the available possibilities. In our examination of state and federal government Web sites, we looked for key features within each Web site that would facilitate connections or interactivity between government and citizens: e-mail, areas to post comments or complaints, chat rooms, search features, broadcasting of government events, and Web site personalization that brings information directly to the attention of citizens.

In general, we found some results that were consistent with transformation and others that fell more squarely within an incrementalist perspective. Most sites have not made much progress at incorporating democracy-enhancing features into their Web sites. It is more common for agencies to emphasize service delivery than overall system performance or democracy enhancement.

The most basic kind of interactivity is e-mail, whereby an ordinary citizen may contact a person in a particular department other than the webmaster. Most sites (84 percent in 2001 and 68 percent in 2000) had this feature, increasing the potential for two-way interaction. However, only half provided search features that allow citizens to find information, the same as in the previous year. And only 15 percent of sites in 2001 had areas to post comments (other than through e-mail), such as message boards (up from 5 percent in 2000). Less than 1 percent offered real-time chat rooms, where citizens can have actual conversations about a government program or agency. Seven percent (up from 2 percent in 2000) made government more accessible by offering live broadcasts of important speeches or events, such as live coverage of Senate or House of Representatives hearings or State of 
the State addresses. Only 5 percent of Web sites allowed citizens to register to receive updates about specific issues using what is called "push technology," that is, automated software that directs e-mails to people with particular interests. Less than 1 percent of sites allowed citizens to personalize an agency's Web site for their own specific interests.

While it is important to have e-mail addresses available on government Web sites, they serve no purpose unless someone actually reads and responds to the messages that are received. To test actual responsiveness, in 2000 we sent e-mail messages requesting official office hours to four agencies in each state (the governor, state legislature, top court, and leading human services agency) and e-mails to 86 federal agencies. We timed responses by the number of business days the agency took to respond and found that government officials were highly responsive. Of the 286 state and federal offices contacted, 91 percent answered our query and 73 percent did so within one day. We repeated this test in 2001 with a slightly more difficult test (asking "how much does it cost to obtain government documents from your agency?") to determine how quickly government bureaucracies responded to a more specific inquiry. The response rate was 80 percent in 2001 (52 percent within a single day), suggesting that in both years technology was being used to enhance democratic performance and responsiveness to citizen questions.

\section{Citizens' Use of E-Government and Its Impact on Trust and Confidence in G overnment}

Beyond the financing, content, and responsiveness of e-government, it is important to examine how the public feels about digital government. The manner in which citizens evaluate e-government is one factor (along with actual service delivery and feelings about traditional government) that will shape how online democracy emerges over the long haul. According to the August 2000 Hart/ Teeter national public opinion survey by the Council for Excellence in Government, slightly over half of Americans (54 percent) say they have visited a federal agency Web site. Even smaller numbers (45 percent and 36 percent, respectively) claim to have gone to a state or local government Web site. These levels of e-government usage suggest that anywhere from half to two-thirds of the adult population remain outside the world of digital government. This poses a serious structural constraint to technology's ability to transform citizens' behavior and attitudes.
In the Hart/Teeter national survey, e-government users tended to be male, younger, better educated, and earned higher incomes than the public as a whole. With the exception of age, these patterns are consistent with other forms of media usage and some types of political participation (Verba and Nie 1972). In general, people of higher education and income participate more, make greater use of information, and read or view media outlets more frequently. Men have higher patterns of media consumption, although women tend to vote more. The only major exception to the typical profile is the relative youth of e-government users. This shows that, at least in some respects, e-government consumers differ from the general category of political participants and media users. ${ }^{6}$ As youthful egovernment users age, it offers more of a possibility for digital service delivery to alter citizens' interactions with government.

In this national survey, federal e-government usage did not have any discernible impact on public trust in government. Some e-government proponents (Gore 1993) have suggested that because digital government offers the potential of improved service delivery at lower costs, it will improve citizens' confidence in the public sector (Nye, Zelikow, and King 1997). To examine this question, the relationship between patterns of e-government usage and four key measures was studied: trust in government, confidence in government, belief that government is effective at solving problems and helping people, and levels of political activity in politics and government. ${ }^{7}$

Table 2 presents the results of an ordinary least squares regression analysis of federal e-government usage on these measures, controlling for party identification, age, education, race, sex, and income. There is no significant relationship between visiting federal government Web sites and views of trust, confidence, or government effectiveness. ${ }^{8}$

\section{Table 2 Impact of E-G overnment Usage on Citizen Attitudes and} Behavior

\begin{tabular}{|c|c|c|c|c|}
\hline & $\begin{array}{l}\text { Trust in } \\
\text { government }\end{array}$ & $\begin{array}{l}\text { Confidence in } \mathrm{E} \\
\text { government }\end{array}$ & $\begin{array}{l}\text { Belief in government } \\
\text { effectiveness }\end{array}$ & $\begin{array}{l}\text { Political } \\
\text { activity }\end{array}$ \\
\hline $\begin{array}{l}\text { Federal government } \\
\text { W eb usage }\end{array}$ & nt .015(.058) & $.097(.088)$ & $-.092(.078)$ & $.314(.090)^{* * *}$ \\
\hline Party identification & $.047(.013)^{* * *}$ & $.087(.020)^{* * *}$ & $.062(.018)^{* * *}$ & $-.053(.020)^{* *}$ \\
\hline Education & $-.0166(.016)$ & $.011(.025)$ & $-.002(.022)$ & $-.084(.026)^{* * *}$ \\
\hline Age & $.006(.01)$ & $.007(.015)$ & $.023(.013)$ & $.002(.016)$ \\
\hline Race & $-.0099(.08)$ & $-.122(.122)$ & $-.161(107)$ & $.219(.126)$ \\
\hline Income & $-.0001(.016)$ & $-.045(.024)$ & $.014(.021)$ & $-.001(.025)$ \\
\hline Sex & $-.030(.056)$ & $-.033(.085)$ & $-.118(.076)$ & $-.074(.088)$ \\
\hline Constant & $2.63(.22)^{* * *}$ & $2.81(.33)^{* * *}$ & $2.70(.29)^{* * *}$ & $2.89(.34)^{* * *}$ \\
\hline$R$ & .20 & .24 & .24 & .30 \\
\hline A djusted $R^{2}$ & .024 & .041 & .040 & .076 \\
\hline $\mathrm{N}$ & 416 & 413 & 410 & 418 \\
\hline \multicolumn{5}{|c|}{$\begin{array}{l}\text { Source: Hart/ Teeter N ational Survey, A ugust, } 2000 \\
\text { Note: N umbers are unstandardized regression coefficients, with standard errors in parentheses. } \\
{ }^{* * *} p<.001 ; * * p<.01\end{array}$} \\
\hline
\end{tabular}


E-government users were no more likely than nonusers to be trusting or confident about government or to believe the government is effective in solving problems. Rather, the most significant predictor of these dimensions was party identification, with strong Democrats most likely to trust government, have confidence in government, and believe that government is effective. The only exception to this pattern was political activity, where there was a significant link to federal e-government use (along with signficant impacts from party identification and education levels). ${ }^{9}$ Those who visited government Web sites (and were Republican and well-educated) were more likely to report they are politically active than those who did not visit government Web sites.

So far, this research has emphasized cross-sectional examination of the impact of e-government on citizens' attitudes and behavior. However, a novel feature of this survey was that it included a component designed to compare citizens' views on two sets of questions: government effectiveness and beliefs that e-government should have a high priority. At the beginning of the survey, each respondent was asked how high a priority it should be for government to invest tax dollars in making information and services available over the Internet, and how effective government actually was. Then, after a series of e-government questions examining which services and information they would like to see online, how much usage has been made of government Web sites, and what they like and fear about e-government, respondents were asked an identical set of questions about government effectiveness and priorities. This before-and-after design allows researchers to investigate questionnaire "priming," that is, the change in each respondent's views after they have been exposed to a variety of e-government questions. This technique is a way to simulate the degree to which the introduction of detailed questions about e-government effects the potential to transform citizen beliefs. If citizens shift toward thinking that government is more effective at problem-solving after hearing about the possible benefits of e-government, it suggests at least the potential for e-government usage to boost citizen confidence in government.

For government effectiveness, respondents were asked, "How effective do you think government is today at solving problems and helping people?" (very effective, fairly effective, fairly ineffective, or very ineffective). For the egovernment priority item, the survey used the question, "In your view, how high a priority should it be for government to invest tax dollars in making information and services available over the Internet?" (very high priority, high priority, medium priority, low priority, or very low priority). Subtracting the before measure from the after measure for each item created two scales dealing with individual-level attitude change. The change in the e-government priority scale ranged from -4 to +4 and measured movement toward (-4) or away from $(+4)$ the view that e-government should be a high priority. The change in the government-effectiveness scale ranged from -3 to +3 and measured movement toward $(-3)$ or away from $(+3)$ the belief that government was effective. In this respect, then, these scales represent an intraquestionnaire technique for measuring short-term attitude change following exposure to e-government information.

As table 3 shows, an ordinary least squares regression analysis demonstrates there were significant changes in the belief that government is effective based on e-government usage and exposure to e-government questions. Those who visited federal government Web sites were more likely during the course of the questionnaire to move in the direction that government is effective. ${ }^{10}$ To put it differently, citizens who were exposed to priming through e-government questions were more likely to express the opinion that government is effective at solving problems. Independently of whether they were Republicans or Democrats or rich or poor (or in other demographic categories), there was an independent e-government effect on underlying confidence in government. Although the overall explanatory power of the effectiveness model was small, the relationship to Web usage still remained significant.

At the same time, federal government Web site visitors were not more likely to believe that e-government is a high priority for public-sector tax investments. This finding is noteworthy because it measures budget receptivity as opposed to general orientations toward government problem solving. Befitting a question dealing with tax funding of new technology, traditional factors such as party identification (with Republicans more opposed than Democrats to spending on information technology) constrained the

\begin{tabular}{|c|c|c|}
\hline \multicolumn{3}{|c|}{$\begin{array}{l}\text { Table } 3 \text { Impact of E-Government Usage on Changes in } \\
\text { Individual Citizen Attitudes }\end{array}$} \\
\hline & $\begin{array}{l}\text { Change in seeing } \\
\text { e-government as priority }\end{array}$ & $\begin{array}{l}\text { Change in seeing } \\
\text { government as effective }\end{array}$ \\
\hline $\begin{array}{l}\text { Federal government } \\
\text { W eb usage }\end{array}$ & $-.199(.104$ & .15 \\
\hline Party identification & $.053(.0$ & -.0 \\
\hline Education & $.016($. & \\
\hline Age & $-.033(.0$ & -.0 \\
\hline Race & -.08 & \\
\hline Income & .0 & -.0 \\
\hline Sex & .01 & \\
\hline Constant & $-.13(.40)$ & -.21 (. \\
\hline$R$ & .2 & \\
\hline A djusted $R^{2}$ & .028 & .007 \\
\hline $\mathrm{N}$ & 418 & 404 \\
\hline \multicolumn{3}{|c|}{$\begin{array}{l}\text { Source: Hart/ Teeter } N \text { ational Survey, A ugust, } 2000 \\
N \text { ote: } N \text { umbers are unstandardized regression coefficients, with standard errors in } \\
\text { parentheses. } \\
* p<.05\end{array}$} \\
\hline
\end{tabular}


ability of e-government usage to affect views about spending priorities.

In short, this priming experiment uses before-and-after questions to suggest that with educational effort about egovernment, citizen beliefs can be transformed in a positive direction for beliefs about government effectiveness, but not spending priorities. As citizens become more informed about and familiar with e-government, public-sector Web site usage has the potential to reshape underlying views about government. Those who make use of government Web sites are more likely to develop positive views about the public sector's effectiveness at solving problems. The same conclusion, however, does not hold for judgments about spending priorities: Those beliefs are more deeply rooted and dependent on long-term feelings about government, such as citizens' partisan leanings.

\section{The Transforming Potential of E-G overnment}

Although it still is early in the e-government revolution, this study suggests that in some respects, digital government has the potential to transform service delivery and citizens' attitudes. Of the hypotheses tested, there was support for several: the presence of large amounts of online information, such as contact information and publications; some use of online services; some measures of responsiveness to citizens, such as the high degree of responsiveness on the e-mail test and the presence of citizen-empowering tools such as search engines and e-mail addresses; public opinions related to the tie between e-government and political activity levels; and positive changes in views about government effectiveness before and after questionnaire priming.

These results suggest that many government agencies have mastered the billboard and partial-service-delivery stages of e-government. In some respects, then, this reaffirms the optimism expressed by proponents of the National Performance Review (Gore 1993) about the transformational power of e-government. The e-mail test points to concrete ways that e-government has already enhanced responsiveness to ordinary citizens. As agency officials learn to harness the power of the Internet, more optimistic results may emerge for service delivery, which could lead to even more positive views about government (Bowie 1996; Fountain 2001b).

In other respects, however, evidence from this research is consistent with incremental rather than transformational change (LaPorte and Demchak 2001; LaPorte et al. 2000; Hinnant 2001). Few government Web sites have progressed to the fully integrated and executable online service delivery or interactive democracy stages. Few jurisdictions have made much progress in incorporating interactive technol- ogy, providing many online services, reassuring the public about security and privacy, or promoting access for special needs populations. Most states are putting a rather small and stable percentage of their overall budget into information technology. For government agencies to realize the transformational power of the Internet, officials need to rely on models that emphasize integration, functionality, and democracy enhancement. They must take on a vision of e-government that moves beyond service delivery to overall system performance.

Given the incremental nature of e-government change, it is little surprise that e-government has not increased trust or confidence in government. Public cynicism has remained strong over three decades of scandals, inefficient performance, and poor economies (Abramson 1983; Maddox and Lilie 1984; Nye, Zelikow, and King 1997). It will take major improvements in government performance-and evidence that technology is responsible for the improvement-in order for the public to transform itself into trusting and noncynical citizens. However, as the questionnaire-priming experiment shows, there is some evidence that exposure to e-government within the body of a questionnaire leads to greater confidence in the online public sector.

Obviously, given the early stage of e-government, researchers should not rush to judge e-government's ability to transform public-sector service performance, democratic responsiveness, or citizen trust in government over the longterm. There are around 87,000 government units in the United States alone, and it will take a long time to determine whether e-government will become a vehicle for the revitalization of democracy (Weber and Brace 1999). The integration of technology into political life is mediated by institutional arrangements, budget scarcity, group conflict, cultural patterns, and individual beliefs and behavior. Many factors constrain bureaucracy's ability to remake itself.

State government spending figures demonstrate that agencies have accomplished a fair amount with fairly limited budget support. Government officials have shown considerable creativity at getting material online without substantial financial resources from Congress or their state legislatures. This demonstrates there are many strategies for developing information technology and e-government. States have piggybacked e-government on other applications (such as developing new computer systems for government agencies), used existing employees, retrained current personnel, and developed partnerships with the private sector and nonprofit organizations.

However, government planners may take several steps to harness the transforming power of the Internet in the public sector. First is the streamlining of government technology offerings. Greater progress needs to be made in creating Web sites that have uniform, integrated, and standardized navigational features. Right now, government Web 
sites have a "Tower of Babel" quality that impedes communication and citizen usage across sites. Every time a citizen logs on to a new government site, he or she must learn how that particular site is organized and where to find particular kinds of material. More consistency across e-government sites would make it easier for citizens to make use of online materials.

Second, there needs to be greater cooperation on the part of government agencies so that one-stop portals and cross-agency offerings are integrated. Government agencies guard their autonomy very carefully, and one of the biggest barriers to e-government improvement has been getting agencies to work together to make sites user friendly. Portal sites that integrate information regardless of the agency source are convenient for citizens and help them avoid the problem of not knowing where to find particular services or information.

Third, agencies need to publicize the existence of government-service portals. According to a 2000 national survey conducted by Hart/Teeter for the Council for Excellence in Government, anywhere from a third to half of Americans (depending on the level of government) have logged onto a public-sector Web site. While some of this access problem reflects a lack of availability of computers and the Internet, many citizens clearly need to be educated as to the existence of online services and information. Marketing tools, such as placing the portal address on state documents, putting the address on vehicle license places (as in Pennsylvania, for example), and using televised public service announcements would help the average citizen learn how to access e-government resources.

Finally, how to pay for e-government infrastructure remains a pressing challenge. While the costs of computing hardware and software have been reduced over the last few years, most states have not made the expansion of e-government a major budgetary priority. The typical American state spends 1 percent-2 percent on information technology, which makes it difficult for there to be rapid progress in placing information and services online. There are, of course, alternative financial models based on commercial advertising and user fees, but each poses risks either in commercializing e-government or relying on user fees that restrict access. The former creates potential conflicts of interest for government agencies, while the latter disenfranchises people of limited means and widens the digital divide between the rich and poor in the United States. Given the revolutionary potential of e-government, it makes sense to support it with tax dollars, the way other government services are financed. In the long run, a flourishing e-government offers great power to improve service delivery for ordinary citizens and business people.

\section{Acknow ledgments}

I would like to thank the editors and reviewers for their suggestions on this article. Their comments helped to make this a better piece of research. I appreciate the financial support of the Brown University Undergraduate Teaching and Research Assistantship program and the Taubman Center for Public Policy at Brown University.

\section{Notes}

1. Names of state chief information officers came from the National Association of State Information Resource Executives (NASIRE), while names of the federal officers came from the Chief Information Officer Council. Of the 88 individuals contacted, 35 answered, for a response rate of 40 percent. Individuals were queried about their views of e-government and how e-government was affecting service delivery, cost, and efficiency.

2. The list of features coded included: office phone number, office address, online publications, online database, external links to other sites, audio clips, video clips, foreign language or language translation, privacy policy, advertisements, security features, toll-free phone number, technical assistance, subject index, frequently asked questions, disability access, services, digital signatures, credit card payments, e-mail address, search capability, comment form, chatroom, broadcast of events, automatic e-mail updates, push technologies that automatically send information to recipients, and personalization features.
3. There is great variation in the type of services available on state government Web sites. The most frequent service found in 2000 was the ability to file taxes online, which was offered by 85 different sites (of the total of 1,680 sites). Other common services included being able to order publications online, filing complaints, registering or renewing vehicle registrations, and ordering hunting licenses.

4. There was a wide variance in the percentage of states' Web sites that had online services in 2001. California was first, with 41 percent of Web sites providing some type of service, followed by Pennsylvania (39 percent), Indiana (38 percent), Ohio (35 percent), Arizona (35 percent), and Michigan (35 percent). States offering few services online included Wyoming ( 0 percent), New Hampshire (3 percent), and Rhode Island (9 percent).

5. We also evaluated the quality of privacy and security statements in 2001 and found that most were weak. Only around 10 percent prohibited commercial marketing of visitor in- 
formation, creation of cookies or individual profiles of visitors, or sharing of personal information without the prior consent of the visitor. In terms of security policies, only 8 percent said they used computer software to monitor network traffic as a way to protect sites against hackers.

6. One interesting finding came in regard to local government Web sites. Unlike the pattern at the state and national level, local e-government users tended to be minorities. Twentytwo percent of those who had visited local sites were minorities, compared to 15 percent of state government Web site users.

7. Like other surveys, citizens in this national sample were cynical about and disengaged from the political process. Only 30 percent said they trusted the government in Washington to do what is right most of the time, while 69 percent felt you could trust it only some of the time or never. Twentysix percent reported they have quite a lot of confidence in the federal government, compared to 30 percent who felt that way about state government and 31 percent who be- lieved it of local government. Fifty-four percent thought the government today is effective at solving problems and helping people. Twenty-seven percent said they are fairly active in politics and government, while 32 said they are somewhat active and 41 percent indicated they are not too active in politics and government.

8. The same was true for state and local Web usage. Using a regression analysis and controlling for the same factors, there were no significant relationships between either one of these items and trust in government, confidence in government, or belief that government is effective.

9. Levels of political activity also were linked to state Web site usage, but not local Web site usage, as judged by a regression analysis controlling for the same factors.

10. There was no significant relationship between changes in beliefs about government effectiveness and e-government priority, and either state or local Web site usage, controlling for the same factors as in the federal e-government model.

\section{References}

Abramson, Paul. 1983. Political Attitudes in America. San Francisco, CA: Freeman.

Bowie, Nolan. 1996. Voting, Campaigns, and Elections in the Future. In Elections in Cyberspace: Toward a New Era in American Politics, edited by Anthony Corrado and Charles Firestone, 69-96. Queenstown, MD: Aspen Institute.

Chadwick, Andrew, with Christopher May. 2001. Interaction between States and Citizens in the Age of the Internet: "EGovernment" in the United States, Britain and the European Union. Paper presented at the annual meeting of the American Political Science Association, August 30-September 2, San Francisco, CA.

Davis, Richard. 1999. The Web of Politics: The Internet's Impact on the American Political System. New York: Oxford University Press.

Fountain, Jane. 1999. The Virtual State: Toward a Theory of Federal Bureaucracy in the 21st Century. In Democracy.com? Governance in a Networked World, edited by in Elaine Kamarck and Joseph Nye, 133-56. Hollis, NH: Hollis Publishing Company.

- 2001a. Public Sector: Early Stage of a Deep Transformation. In The Economic Payoff from the Internet Revolution, edited by the Brookings Task Force on the Internet, 23568. Washington, DC: Brookings Institution.

- 2001b. Building the Virtual State: Information Technology and Institutional Change. Washington, DC: Brookings Institution.

Gore, Al. 1993. From Red Tape to Results: Creating a Government That Works Better and Costs Less. New York: Times Books.

Hinnant, Chris. 2001. Adoption of E-Services in State Agencies. Paper presented at the annual meeting of the American Political Science Association, August 30-September 2, San Francisco, CA.
Kamarck, Elaine, and Joseph Nye, eds. 1999. Democracy.com? Governance in a Networked World. Hollis, NH: Hollis Publishing Company.

LaPorte, Todd, and Chris Demchak. 2001. Revolution or Evolution? Public Agencies, Networked Information Technologies and Democratic Values in the United States and Around the World. Paper presented at the annual meeting of the American Political Science Association, August 30-September 2, San Francisco, CA.

LaPorte, Todd, Chris Demchak, Martin de Jong, and Christian Friis. 2000. Democracy and Bureaucracy in the Age of the Web. Paper presented at the International Political Science Association World Congress, August 4-6, Quebec.

Lindblom, Charles. 1959. The Science of "Muddling Through." Public Administration Review 29(1): 79-88.

Maddox, William, and Stuart Lilie. 1984. Beyond Liberal and Conservative. Washington, DC: Cato Institute.

Margolis, Michael, and David Resnick. 2000. Politics as Usual: The Cyberspace "Revolution." Thousand Oaks, CA: Sage Publications.

Markoff, John. 2000. A Newer, Lonelier Crowd Emerges in Internet Study. New York Times, February 16, A1.

Musso, Juliet, Christopher Weare, and Matt Hale. 2000. Designing Web Technologies for Local Governance Reform: Good Management or Good Democracy? Political Communication 17(1): 1-19.

Nye, Joseph, Philip Zelikow, and David King. 1997. Why People Don't Trust Government. Cambridge, MA: Harvard University Press.

Quinn, James Brian. 1992. Intelligent Enterprise. New York: Free Press.

Raney, Rebecca. 2000. Study Finds Internet of Social Benefit to Users. New York Times, May 11, E7. 
Thompson, Dennis. 1999. James Madison on Cyberdemocracy. In Democracy.com? Governance in a Networked World, edited by Elaine Kamarck and Joseph Nye, 35-42. Hollis, NH: Hollis Publishing Company.

Verba, Sidney, and Norman Nie. 1972. Participation in America: Political Democracy and Social Equality. New York: Harper and Row.

Weber, Ronald, and Paul Brace, eds. 1999. American State and Local Politics. New York: Chatham House.

Wildavsky, Aaron. 1984. The Politics of the Budgetary Process. 4th ed. Boston: Little, Brown.
Appendix Hart/ Teeter National Public Opinion Survey for the Council for Excellence in Government, August 14-16, 2000 ( $N=1,003$ adults)

Political Activity- How active would you say you are in politics and government: (1) very active; (2) fairly active; (3) just somewhat active; or (4) not too active.

Confidence in Federal Government- I am going to read a list of institutions in A merican society and I'd like you to tell me how much confidence you have in each one: federal government (1) a great deal; (2) quite a lot; (3) some; or (4) very little confidence.

Trust in Government- How much of the time do you think you can trust the government in W ashington to do what is right: (1) just about always; (2) most of the time; (3) only some of the time; or (4) never.

Government Effectiveness- How effective do you think government is today at solving problems and helping people: (1) very effective; (2) fairly effective; (3) fairly ineffective; or (4) very ineffective.

E-Government Priority - In your view, how high a priority should it be for government to invest tax dollars in making information and services available over the Internet: (1) a very high priority; (2) a high priority;

(3) a medium priority; (4) a low priority; or (5) a very low priority.

Use of Federal Government Web site- Have you ever visited the Web site of a federal agency? (1) yes, have visited Web site; (2) no, have not visited $\mathrm{W}$ eb site.

Use of State Government Web site- Have you ever visited the W eb site of a department of your state government? (1) yes, have visited W eb site; (2) no, have not visited W eb site.

Use of Local Government Web site- Have you ever visited the W eb site of a department of your local government? (1) yes, have visited W eb site; (2) no, have not visited W eb site.

Sex- (1) male; (2) female.

Age- How old are you? (1) 18-24; (2) 25-29; (3) 30-34; (4) 35-39; (5) $40-44$; (6) $45-49$; (7) 50-54; (8) 55-59; (9) 60-64; (10) 65-69;

(11) $70-74 ;$ (12) 75 and over.

Race-A re you from a Hispanic or Spanish-speaking background? If no, what is your race: (1) Hispanic, (2) white, (3) black (4) A sian (5) other- $\mathrm{N}$ ote: recoded as (1) minority (2) white

Income- If you added together the yearly income of all the members of your family who were living at home last year, would the total be: (1) less than $\$ 10,000$; (2) between $\$ 10,000$ and $\$ 20,000$; (3) between $\$ 20,000$ and $\$ 30,000$; (4) between $\$ 30,000$ and $\$ 40,000$; (5) between $\$ 40,000$ and $\$ 50,000$; (6) between $\$ 50,000$ and $\$ 75,000$; (7) between $\$ 75,000$ and $\$ 100,000$; (8) more than $\$ 100,000$.

Education- $W$ hat is the last grade that you completed in school: (1) grade school; (2) some high school; (3) high school graduate; (4) some college, no degree; (5) vocational training, two-year college; (6) fouryear college/ bachelor's degree; (7) some postgraduate work, no degree; (8) two to three years' postgraduate work, master's degree; (9) doctoral degree/ law degree.

Party Identification - G enerally speaking, do you think of yourself as a Democrat, a Republican, an independent, or something else? Would you call yourself a strong Democrat/ Republican or not a very strong Democrat/ Republican? Do you think of yourself as closer to the Republican Party, closer to the Democratic party, or do you think of yourself as strictly independent? [Coded as a 1 to 7 party identification scale, with 1 being a strong Democrat and 7 being a strong Republican.] 